\title{
Результати хірургічного лікування місцево-розповсюдженого раку ободової кишки з поширенням на підшлункову залозу
}

\section{В. В. Керничний ${ }^{1,2}$, А. І. Суходоля ${ }^{1,2}$, В. М. Монастирський ${ }^{1,2}$, В. А. Мороз ${ }^{1,3}$, В. В. Балицький ${ }^{1,2}$, О. О. Підмурняк ${ }^{1,2}$ \\ ${ }^{1}$ Вінницький національний медичний університет імені М. І. Пирогова, ${ }^{2}$ Хмельницька обласна лікарня, \\ ${ }^{3}$ Хмельницький обласний онкологічний диспансер \\ Results of surgical treatment of locally-spread colon cancer with pancreatic spread}

\author{
V. V. Kernychnyi ${ }^{1,2}$, A. I. Sukhodolia ${ }^{1,2}$, V. M. Monastyrskyi ${ }^{1,2}$, V. A. Moroz ${ }^{1,3}$, \\ V. V. Balytskyi ${ }^{1,2}$, O. O. Pidmurniak ${ }^{1,2}$ \\ ${ }^{1}$ Vinnytsya National Medical University named after M. I. Pyrogov, \\ ${ }^{2}$ Khmelnytskyi Regional Hospital, \\ ${ }^{3}$ Khmelnytskyi Regional Oncological Dispenser
}

\section{Реферат}

Мета. Поділитися власним досвідом хірургічного лікування місцево-розповсюдженого раку ободової кишки 3 поширенням на підшлункову залозу (ПЗ).

Матеріали і методи. Вивчено результати хірургічного лікування 24 хворих з місцево-розповсюдженим раком ободової кишки, що поширювався на П3, за $2004-2015$ рр. Чоловіків було 8 (33\%), жінок - 16 (67\%). Середній вік пацієнтів становив (65,2 $\pm 11,2)$ року. Рак ободової кишки, окрім П3, проростав у паранефральну клітковину зліва - у 6 (25\%) пацієнтів, селезінку - у 5 (20,8\%), дванадцятипалу кишку (ДПК) - у 3 (12,5\%), шлунок - у 1 (4,1\%), тонку кишку - у 1 (4,1\%), черевну стінку - у 1 (4,1\%). Пацієнтів розподілили на дві групи. Хворим групи I - 13 (54,1\%) - виконували симптоматичні оперативні втручання, групи II - 11 $(45,8 \%)$ - радикальні.

Результати. Тривалість життя хворих після симптоматичних оперативних втручань становила (5,1 \pm 3$)$ міс. У 3 (23,0\%) хворих післяопераційних ускладнень не спостерігали. Післяопераційні ускладнення (за класифікацією Clavien-Dindo) I ступеня виявлені у 5 (38,4\%) хворих, II - у 2 (15,3\%), IVa - у 1 (7,6\%), V - у 2 (15,3\%). Причинами смерті в ранні строки після операції 2 хворих з післяопераційними ускладненнями V ступеня стали профузна шлунково-кишкова кровотеча - у 1 (7,6\%) та тромбоемболія легеневої артерії (ТЕЛА) - у 1 (7,6\%).

Тривалість життя хворих після радикальних оперативних втручань становила (19,5 \pm 14$)$ міс. Виконано такі оперативні втручання: дистальну резекцію ПЗ - у 10 (91\%) хворих, панкреатодуоденальну резекцію - у 1 (9\%). У 3 (27,2\%) хворих післяопераційних ускладнень не спостерігали. Післяопераційні ускладнення (за класифікацією Clavien-Dindo) I ступеня виявлені у 3 (27,2\%) хворих, IIIa - у 1 (9\%), IVa - у 1 (9\%), V - y 2 (18,1\%). Померли 2 (18,1\%) хворих від тяжких гнійно-септичних ускладнень. Висновки. Пацієнтам з раком ободової кишки, який поширюється на ПЗ, але без віддалених метастазів, низьким індексом коморбідності - Charlson Comorbidity Index (CCI) та оцінкою за шкалою ECOG (Eastern Cooperative Onkology Group) менше 2 балів рекомендовано виконувати мультивісцеральну резекцію, у тому числі резекцію ПЗ

ключові слова: рак ободової кишки; мультивісцеральна резекція; резекція підшлункової залози.

\section{Abstract}

Objective. To disseminate own experience of surgical treatment of locally-extended colonic cancer with pancreatic spreading Materials and methods. Results of surgical treatment of 24 patients (in 2004 - $2015 \mathrm{yrs}$ ), suffering locally-extended colonic cancer with pancreatic spreading, were studied. There were $8(33 \%)$ men and $16(67 \%)$ women. Average age of the patients have constituted (65.2 \pm 11.2$)$ yrs old. Colonic cancer, besides pancreatic gland, have spreaded into paranephral cellular tissue - in $6(25 \%)$ patients, spleen - in $5(20.8 \%)$, duodenum - in $3(12,5 \%)$, stomach - in $1(4.1 \%)$, small bowel - in $1(4.1 \%)$, abdominal wall - in $1(4.1 \%)$. The patients were divided into two groups. Of the patients of Group I in 13 (54.1\%) symptomatic operative interventions were performed and in $11(45.8 \%)$ of those of the Group II - radical.

Results. The patients' survival after symptomatic operative interventions have constituted $(5.1 \pm 3) \mathrm{mo}$. In $3(23.0 \%)$ patients morbidity was absent. Postoperative complications (in accordance to Clavien-Dindo classification) of the Degree I were revealed in 5 (38,4\%) patients, II - in 2 (15.3\%), IVa - in 1 (7.6\%), and V - in 2 (15.3\%). Early postoperative lethality was caused by the V Degree morbidity: profuse gastro-intestinal hemorrhage - in 1 (7.6\%) and pulmonary thromboembolism - in $1(7.6 \%)$.

The survival of patients after radical operative interventions have constituted $(19.5 \pm 14)$ mo. There were performed following operative interventions: distal pancreatic resection - in 10 (91\%) patients, pancreaticoduodenal resection - in 1 (9\%). In $3(27.2 \%)$ patients postoperative complications were not revealed. Postoperative complications (in accordance to Clavien-Dindo classification) of the Degree I were detected in $3(27.2 \%)$ patients, IIIa - in 1 (9\%), IVa - in 1 (9\%), and V - in $2(18.1 \%)$. Because of severe purulent-septic complications $2(18.1 \%)$ patients died.

Conclusion. In colonic cancer with pancreatic spread, in the absence of remote metastases, low index of comorbidity by Charlson Comorbidity Index (CCI) and estimation in accordance to the ECOG scale lesser then 2 points it is recommended to perform multivisceral resection, including pancreatic resection.

Keywords: colon cancer; multivisceral resection; pancreatic resection. 
Колоректальний рак залишається одним із найбільш поширених злоякісних захворювань як в Україні, так і у світі. Висока захворюваність на колоректальний рак та збільшення частки хворих з його місцево-розповсюдженими формами зумовлюють виконання мультивісцеральної резекції як єдиного радикального методу лікування даної категорії хворих. Однак рак ободової кишки Т4, який поширюється на ПЗ, діагностують вкрай рідко, тому й повідомлень про результати хірургічного лікування цього захворювання дуже мало. У ряді публікацій автори доводять доцільність виконання єдиним блоком панкреатодуоденальної, сегментарної та дистальної резекцій Пз в обсязі R0 $[1,2]$. Історично ці операції асоційовані з тяжкими післяопераційними ускладненнями та смертністю [3]. Однак за останні десятиліття в спеціалізованих хірургічних центрах післяопераційна смертність знизилась до 5\% [2], що викликало зацікавленість до розширення ділянок резекції за межі стандартних геміколектомій для досягнення обсягу R0.

Мета дослідження: поділитися власним досвідом хірургічного лікування місцево-розповсюдженого раку ободової кишки з поширенням на ПЗ.

\section{Матеріали і методи дослідження}

Проведено мультицентровий ретроспективний аналіз результатів хірургічного лікування 1158 хворих із раком ободової кишки на базі Хмельницького обласного онкологічного диспансеру та проктологічного і хірургічного відділень Хмельницької обласної лікарні за період з січня 2004 по грудень 2015 р. Із 1158 хворих у 24 (2\%) діагностовано місцево-розповсюджений рак ободової кишки, що поширювався на ПЗ. Рак поперечної ободової кишки виявлено у 3 (12,5\%) пацієнтів, селезінкового згину ободової кишки - у 18 (75\%), низхідної ободової кишки - у 3 (12,5\%); аденокарциному G2 - у 15 (62,5\%), G3 - у 9 $(37,5 \%)$; метахронний рак лівої нирки - у 1 (4,2\%) пацієнта. Органи, окрім П3, в які проростав рак ободової кишки: паранефральна клітковина зліва - 6 (25\%) хворих, селезінка - 5 (20,8\%), ДПК - 3 (12,5\%), шлунок - 1 (4,2\%), тонка кишка - 1 (4,2\%), черевна стінка - 1 (4,2\%).

Пацієнтів розподілили на дві групи. Хворим групи I 13 (54,1\%) - виконували симптоматичні оперативні втручання, групи II - 11 (45,8\%) - радикальні.

Порівнювані групи не мали статистично значущої різниці за віковими показниками та мало відрізнялися за статевими ознаками. Середній вік чоловіків у групі І становив $(61,5 \pm 4,9)$ року, у групі II - $(63,5 \pm 16,7)$ року, жінок відповідно $(70 \pm 12,7)$ та $(62,2 \pm 7,8)$ року $(\mathrm{p}=0,32)$. У групі І чоловіків було 4 (30,7\%), жінок - 9 (69,3\%), у групі II відповідно 4 (36,3\%) і 7 (63,7) (p=0,78).

\section{Результати}

Поширеність онкологічного процесу у пацієнтів групи I: $\mathrm{T}_{4} \mathrm{~N}_{0} \mathrm{M}_{0}-2$ (15,3\%); $\mathrm{T}_{4} \mathrm{~N}_{1-2} \mathrm{M}_{0}-3$ (23\%); $\mathrm{T}_{4} \mathrm{~N}_{1-2} \mathrm{M}_{1}-8$ (61,5\%). Віддалені синхронні метастази: Mts OSS (Th-12) - 1 (7,6\%); Mts HEP - 4 (30,7\%); Mts HEP, PER - 8 (61,5\%).

Поширеність онкологічного процесу у пацієнтів групи II: $\mathrm{T}_{4} \mathrm{~N}_{0} \mathrm{M}_{0}-5$ (45,5\%); $\mathrm{T}_{4} \mathrm{~N}_{1-2} \mathrm{M}_{0}-5$ (45,5\%); $\mathrm{T}_{4} \mathrm{~N}_{0} \mathrm{M}_{1}-1$ (9\%). Віддалені синхронні метастази: Mts HEP (Sg3) - 1 (9\%). За ураженням лімфатичних вузлів $\mathrm{pN}_{0}$ та $\mathrm{pN}_{1-2}$ групи відрізнялись статистично достовірно (p=0,04). Метахронні метастази у групі I виявлені у 1 (7,6\%) хворого через 5 міс після оперативного втручання: Mts LYM (Вірхова), у 1 (7,6\%) через 7 міс: Mts PER (канцероматоз). Метахронні метастази у групі II виявлені у 1 (9\%) хворого через 40 міс після операції: Mts HEP (множинні білобарні), у 1 (9\%) - через 18 міс: Mts PER (Крукенберга).

Супутню патологію у групах I та II оцінювали за CCI, який становив $8 \pm 2,2$ і $5 \pm 2$ відповідно ( $=0,009)$. Як відомо, ССІ є незалежним фактором, що впливає на результат хірургічного лікування [4]. Виходячи з отриманих даних, пацієнти груп I і II мали тяжку супутню патологію, яка негативно впливала на післяопераційну реабілітацію незалежно від об'єму виконаного оперативного втручання.

Загальний передопераційний стан пацієнтів груп I і II, оцінений за шкалою ECOG, достовірно відрізнявся і становив більше 2 балів та менше 2 балів відповідно ( $\mathrm{p}=0,001)$.

Пацієнтам групи I виконані такі симптоматичні хірургічні втручання: трансверзостомія - 6 (46,1\%), формування обхідних міжкишкових анастомозів - 5 (38,4\%) та шлунково-кишкових анастомозів - 2 (15,3\%).

У пацієнтів групи II оперативні втручання були такими: дистальна резекція ПЗ - 10 (91\%), панкреатодуоденальна резекція - 1 (9\%). Оперативні втручання, виконані на ободовій кишці: розширена лівобічна геміколектомія - 8 (72,7\%) хворих, розширена правобічна геміколектомія - 1 (9\%), субтотальна центральна колектомія - 1 (9\%), резекція поперечної ободової кишки - 1 (9\%). Оперативні втручання на інших органах полягали у спленектомії - 3 (27,2\%) хворих, холецистектомії - 3 (27,2\%), резекції тонкої кишки - 1 (9\%), резекції печінки - 1 (9\%), ліквідації колостоми - 2 (18\%). $\mathrm{R}_{0}$-резекцію виконано у 11 (100\%) пацієнтів.

Загалом частота тяжких післяопераційних ускладнень IIIa-V ступенів за шкалою Clavien-Dindo становила 23 та 36,3\% у групах I і II відповідно. Через 30 днів після операції померли 4 пацієнти: у групі I - 2 (15,2\%) і у групі II 2 (18,1\%). У групі I причиною смерті 2 пацієнтів 3 післяопераційними ускладненнями V ступеня стали профузна шлунково-кишкова кровотеча - 1 (7,6\%) та ТЕЛА - 1 (7,6\%). Причиною смерті 2 пацієнтів з післяопераційними ускладненнями V ступеня у групі II були тяжкі гнійносептичні ускладнення.

Релапаротомію виконали 1 (7,6\%) пацієнту групи I та 3 (27,2\%) - групи II. Причиною релапаротомії у пацієнтів групи I була профузна кровотеча з гострої виразки ДПК, у пацієнтів групи II - панкреонекроз, кровотеча з передньої верхньої підшлунково-дванадцятипалокишкової артерії та неспроможність міжкишкового анастомоза.

Строки перебування хворих груп I та II на стаціонарному лікуванні становили в середньому $(21 \pm 6)$ та (29 \pm 12) ліжко-днів відповідно.

Аналіз даних нашого дослідження показав, що однорічна виживаність пацієнтів групи І становила 7,6\%, групи II - 63,7\% (p=0,002). Трирічна виживаність у групі I не зафіксована, у групі II цей показник становив 18,1\% (p=0,1). Таким чином, медіана виживаності у групах I та II становила $(5,1 \pm 3)$ і $(19,5 \pm 14)$ міс $(p=0,01)$ відповідно. 


\section{Обговорення}

Проаналізувавши результати лікування хворих з місцево-розповсюдженим раком ободової кишки з поширенням на ПЗ, найперше ми звернули увагу те, що їх частка була досить незначна - 2\% від усіх досліджуваних хворих із раком ободової кишки. У той же час місцево-розповсюджений рак ободової кишки з поширенням на інші органи виявляють часто і так само часто успішно оперують. Однак, коли пухлина ободової кишки проростає в П3, перед хірургом постає завдання виконати оперативне втручання, яке виходить далеко за межі класичних стандартних і нестандартних операцій.

На нашу думку, група пацієнтів, яким проводили симптоматичне хірургічне лікування, була досить численною, адже, окрім місцево-розповсюдженого процесу, загальний стан пацієнтів як за СCI $(8 \pm 2,2)$, так і за ускладненим перебігом раку ободової кишки (більше 2 балів за шкалою ECOG) був досить тяжким для того, щоб прийняти рішення про радикальне оперативне втручання. I, незважаючи на симптоматичну хірургічну тактику, частка тяжких ускладнень IIIa-V ступенів за шкалою Clavien-Dindo становила 23\%.

У групі пацієнтів, яким проводили радикальне хірургічне лікування, CCI і оцінка за шкалою ECOG були значно нижчими. У них у ранньому післяопераційному періоді частка тяжких ускладнень (IIIa-V ступенів) становила 36,3\%, летальність - 18,1\%, що, на нашу думку, є досить високими показниками. Така ситуація пов'язана із труднощами реабілітації даної категорії пацієнтів. Водночас ме-

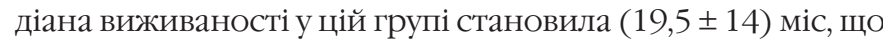
майже в 4 рази перевищує відповідний показник у пацієнтів, яким виконані симптоматичні оперативні втручання.

\section{Висновки}

1. Пацієнтам з раком ободової кишки, який поширюється на ПЗ, але без віддалених метастазів, з низьким ССІ та оцінкою за шкалою ECOG менше 2 балів доцільно виконувати мультивісцеральну резекцію, в тому числі резекцію ПЗ.

2. У пацієнтів з місцево-розповсюдженим раком ободової кишки, який поширюється на ПЗ, без віддалених метастазів, але з високим ССI та оцінкою за шкалою ECOG більше 2 балів рекомендовано на першому етапі провести корекцію коморбідних станів та досягти компенсації життєвих показників організму. Мультивісцеральна резекція має бути наступним етапом лікування.

3. У пацієнтів з раком ободової кишки, який поширюється на ПЗ, з віддаленими метастазами, високим ССІ та оцінкою за шкалою ECOG більше 2 балів необхідно застосовувати симптоматичну хірургічну тактику.

\section{References}

1. Won-Suk L, Woo Yong L, Ho-Kyung C, Seong-Ho C. En bloc resection for right colon cancer directly invading duodenum or pancreatic head. Yonsei Med J. 2009 Dec;50(6):803-6.

2. Sara JT, Peter TWK, Pablo ES, Daniel K, Sean PC, Carol-Anne M, et al. Combined pancreaticoduodenectomy and colon resection for locally advancen peri-ampullary tumours: analysis of peri-operative morbidity and mortality. HPB. 2014 Sep;16(9):797-0.

3. Whipple A. The rationale of radical surgery for cancer of the pancreas and ampullary region. Ann Surg. 1941 Oct;114(4):612-5.

4. Wen-Chi C, Keng-Hong L, Chang-Hsien L, Yu-Shin H, Miao-Fen C, $\mathrm{Yu}-$ fan $\mathrm{C}$, et al. To Operate or not: Prediction of 3-month postoperative mortality in geriatric cancer patients. J Cancer. 2016;(7)1:14-21. 